\title{
New Concepts on Pathogenesis and Diagnosis of Liver Fibrosis; A Review Article
}

\author{
Hedyeh Ebrahimi $\uparrow^{1}$, Mohammadreza Naderian $\uparrow^{1}$, Amir Ali Sohrabpour ${ }^{2 *}$
}

1. Liver and Pancreaticobiliary Diseases Research Center, Digestive Disease Research Institute, Shariati Hospital, Tehran University of Medical Sciences, Tehran, Iran. Non-Communicable Diseases Research Center, Endocrinology and Metabolism Population Sciences Institute, Tehran University of Medical Sciences, Tehran, Iran.

2. Assistant Professor, Liver and Pancreaticobiliary Diseases Research Center, Digestive Disease Research Institute, Shariati Hospital, Tehran University of Medical Sciences, Tehran, Iran

$\uparrow$ : These two authors contributed equally to this work.

\footnotetext{
* Corresponding Author:
}

Amir Ali Sohrabpour, MD Shariati hospital, North Kargar St., Tehran, Iran.

Tel: +98 2182415400

Fax: + 982182415000

Email: aasohrabpour@tums.ac.ir

Received: 11 Apr. 2016

Accepted: 25 Jun. 2016

\section{ABSTRACT}

Liver fibrosis is a potentially reversible response to hepatic insults, triggered by different chronic diseases most importantly viral hepatitis, alcoholic, and nonalcoholic fatty liver disease. In the course of the chronic liver disease, hepatic fibrogenesis may develop, which is attributed to various types of cells, molecules, and pathways. Activated hepatic stellate cell (HSC), the primary source of extracellular matrix (ECM), is fundamental in pathophysiology of fibrogenesis, and thus is the most attractable target for reversing liver fibrosis. Although, liver biopsy has long been considered as the gold standard for diagnosis and staging of hepatic fibrosis, assessing progression and regression by biopsy is hampered by its limitations. We provide recent views on noninvasive approaches including serum biomarkers and radiologic techniques.

\section{KEYWORDS}

Liver Cirrhosis; Fibrosis; Pathogenesis; Diagnosis; Therapeutics; Genetic Therapy

\section{Please cite this paper as:}

Ebrahimi H, Naderian M, Sohrabpour AA. New Concepts on Pathogenesis, Diagnosis, and Targeting of Liver Fibrosis; A Review Article. Middle East J Did Dis 2016;8:166-178. DOI:10.15171/mejdd.2016.29.

\section{INTRODUCTION}

Liver fibrosis is in fact a healing response to liver injury and is characterized by excessive deposition of extracellular matrix (ECM) proteins as a result of different chronic liver diseases including viral hepatitis, alcoholic or non-alcoholic steatohepatitis. ${ }^{1-3}$ Liver fibrosis is beneficial at first because it can encapsulate the injury, and is considered a reversible process at this stage ${ }^{4-8}$, but ultimately progresses to advanced fibrosis or cirrhosis, that might be irreversible and causes impaired liver function and subsequent morbidity and mortality. ${ }^{9}$

Cirrhosis may cause serious complications such as hepatocellular carcinoma or bleeding from esophageal varices and invariably leads to death. ${ }^{10}$ In the United States alone, cirrhosis is one of the leading causes of death and results in a significant burden as high as $\$ 2$ billion. $.^{11,12} \mathrm{Ac}-$ cording to global burden of disease (GBD) study in 2013, cirrhosis is among the 10 most common causes of death in different world areas and the 6th cause of death in developed countries. ${ }^{13}$ The burden is expected to rise in the forthcoming years due to increasing prevalence of cirrhotic cases related to non-alcoholic steatohepatitis (NASH) and hepatitis $\mathrm{C}$ virus (HCV) infection. ${ }^{14,15}$ Thus, cirrhosis and liver transplantation is expected to be among important challenges in the 21 st century. ${ }^{10}$

Major advances have occurred in the field of liver fibrosis in recent years. Development of non-invasive strategies to detect liver fibrosis has 
enabled clinicians to diagnose at-risk patients rapidly and readily. ${ }^{16}$

The aim of this paper is to review recent achievements in pathogenesis and diagnostic evaluation of liver fibrosis.

\section{Pathogenesis}

Liver fibrogenesis is a dynamic interaction between cellular and molecular processes. Although different diseases might result in liver fibrosis, there are common features. ${ }^{17}$ Defining mechanisms that contribute to liver fibrosis in each will direct future research toward discovery of therapeutic targets. ${ }^{18}$

Hepatic fibrosis can be regarded as the result of an imbalance between ECM synthesis and degeneration. The balance between matrix metalloproteinases (MMPs) and tissue inhibitors of metalloproteinase (TIMPs) is crucial for ECM homeostasis.

\section{Cell types}

Different populations of cells play roles in fibrogenesis, but activation of hepatic stellate cells (HSCs) is an essential factor in fibrogenesis. ${ }^{19,20}$

Liver myofibroblasts (MF) include a heterogeneous population of highly proliferative cells that accumulate at injury sites and promote ECM accumulation. ${ }^{21}$ Myofibroblast pool originates mainly from liver mesenchymal cells, namely HSCs. ${ }^{22}$ Although HSCs are the primary source of MFs in liver fibrosis, extrahepatic precursors such as bone marrow derived mesenchymal cells and portal fibroblasts contribute in ECM synthesis. ${ }^{23-26}$ Other minor sources of MFs are cells that undergo epithelial-mesenchymal transition (EMT).$^{27}$ However, some recent findings raise doubt about potential epithelial origin of ECM-producing cells. ${ }^{28-30}$

\section{Hepatic stellate cells (HSC)}

Hepatic stellate cells (HSCs) are one of the nonparenchymal cells of the liver, residing adjacent to sinusoids, in the space of Disse. In liver tissues, HSCs store retinoids such as vitamin A and produce glial fibrillary acidic protein (GFAP), reasoning their former names fat-storing cells or vitamin A-rich cells. ${ }^{31-35}$ Since trans-differentiations are seen among HSCs in some pathologic conditions, it has been speculated that HSCs may originate from mesoderm-derived multipotent mesenchymal progenitor cells (MMPCs). These progenitor cells generate several neural cell lineages as well as other mesenchymal cells. ${ }^{36-38}$

Autocrine and paracrine secretion of fibrogenic cytokines as a result of pathologic insults to liver cells, promote HSCs to trans-differentiate, changing from a quiescent phenotypes to an activated myofibroblastic state. These fibrogenic cytokines include tumor necrosis factor $\alpha$ (TNF- $\alpha)$, transforming growth factor $\beta$ (TGF- $\beta$ ), interleukin 1 (IL1 ), and platelet-derived growth factor (PDGF). ${ }^{39-43}$ Activated HSCs express fibrogenic proteins and $\alpha$-smooth muscle actin ( $\alpha$-SMA) and lose their lipid and retinoid storages, transitioning from an adipogenic state to a fibrogenic, chemotactic, and mitogenic one. ${ }^{44,45}$

\section{Hepatocytes}

Hepatocytes, the parenchymal component of liver, are the main target of hepatitis viruses, alcohol toxicity, steatosis and other hepatotoxic agents. Chronic liver injury promotes hepatocyte apoptosis through TNF- $\alpha$ related apoptosis inducing ligand (TRAIL) and Fas. ${ }^{46,47}$ Some reports have shown that hepatocyte-derived apoptotic bodies stimulate secretion of fibrogenic cytokines from macrophages and also promote HSCs activation via interaction of toll-like receptor 9 (TLR9) with DNA, which is released from apoptotic hepatocytes. ${ }^{48-51}$ On the other hand, Jiang JX et al. showed that activated HSCs also can act as phagocytes and phagocytize hepatocyte apoptotic bodies which promotes myofibroblasts survival and fibrogenesis. ${ }^{52}$ Hypoxic hepatocytes in cirrhotic stages are primary sources for secretion of TGF- $\beta$, which may augment liver fibrosis. ${ }^{53}$

Hepatocyte telomerase shortening independent of age, can promote scarring and progression of fibrosis. ${ }^{54}$ Studies on telomerase-deficient mice revealed that shortened telomeres due to chronic liver injury are associated with impaired liver regeneration and accelerated fibrosis development. ${ }^{55}$ 


\section{Liver sinusoidal endothelial cells (LSECs)}

The prominent characteristic of liver sinusoidal endothelial cells (LSECs), also known as endothelium, in the normal liver is their fenestrae which control exchange of fluids and particles between hepatocytes and sinusoidal blood. ${ }^{56}$ The fenestrated endothelial cells also suppress activation of HSCs through vascular endothelial growth factor (VEGF) stimulated nitric oxide (NO) production. ${ }^{57}$

Upon liver injuries, defenestration and capillarization of LSECs result in disturbances in substrate exchange, the main cause of liver dysfunction in fibrosis. ${ }^{58}$ Moreover, capillarized LSECs leads to HSCs activation..$^{59,60}$

\section{Kupffer cells}

Kupffer cells (KCs), also called stellate macrophages, are usually activated by multiple injuries such as viral hepatitis and alcohol consumption. ${ }^{61}$ Activation of KCs is a key step in initiation and preservation of fibrosis. Activated forms of these cells express chemokine receptors, secret inflammatory cytokines and act as antigen presenting cells in viral hepatitis, which lead to progression of liver fibrosis. ${ }^{62-64} \mathrm{KCs}$ activate HSCs, and are observed to be engulfing apoptotic particles, which result in fibrogenesis. ${ }^{65}$

\section{Role of cytokines}

Liver fibrosis is a consequence of interaction of a complex network of cytokines, which modify activities of circulating immune cells, HSCs, KCs, LSECs, and hepatocytes. In Table 1, we have listed the groups of cytokines which enhance or alleviate liver fibrogenesis. However, the effect of cytokines may differ in pathogenesis of different liver diseases.

Pathogenesis of fibrosis in specific liver diseases Viral hepatitis

Cell death markers such as cytokeratin 18 and alanine aminotransferase (ALT) are found to correlate with fibrosis stage, so hepatocyte death triggered by hepatotropic viruses is considered an essential step in progression of fibrosis in viral hepatitis. ${ }^{107,108}$
Hepatitis B virus (HBV) viral protein, HBx, induces paracrine activation and proliferation of HSCs and enhances the expression of TGF- $\beta$, $\alpha$-SMA and collagen type I ${ }^{109}$

Nonstructural hepatitis $\mathrm{C}$ virus (HCV) proteins, such as NS3 and NS5 may directly activate intracellular pathways within HSCs and promote their activation. $\mathrm{HCV}$ infection also causes mitochondrial dysfunction and oxidative stress in hepatocytes. ${ }^{110}$ Chronic infection with this virus leads to cell cycle arrest in hepatocyte in G1 stage and inhibits hepatocytes regeneration. ${ }^{1,111}$

\section{-Alcoholic liver disease (ALD)}

Liver fibrosis in chronic exposure to ethanol is caused by generation of acetaldehyde. Acetaldehyde stimulates production of TGF- $\beta$, TNF- $\alpha$, IL- 1 , reactive oxygen species (ROS), and collagen type I . ${ }^{112}$ Cytochrome P450 (in particular CYP2E1) has an essential role in production of ROS. ${ }^{113}$

Excessive ethanol consumption leads to reduction of glutathione mediated protection of hepatocytes against ROS and induces hepatocyte apoptosis through downregulation of Bcl-2 signaling pathway. ${ }^{114,115}$ Ethanol induces fibrogenic activity of HSCs by inhibition of autophagy, which results in endoplasmic reticulum stresses and inhibits natural killer (NK) cells' anti-fibrogenic functions by enhancing production of TGF- $\beta$ by HSCs. ${ }^{116}$

Several studies have demonstrated that level of circulating lipopolysaccharide (LPS) is significantly higher in alcohol consumers. LPS promotes activation of TLR4 signaling pathway in HSCs and LSECs leading to liver fibrosis. ${ }^{117,118}$

\section{Non-alcoholic fatty liver disease (NAFLD)}

Fibrosis progression in non-alcoholic steatohepatitis (NASH) can be caused by several triggers, some to mention are: 1: oxidative stresses by increased ROS production due to excess accumulation of lipids in the hepatocyte ${ }^{119} ; 2$ : induction of inflammatory states through release of proinflammatory cytokines from adipose tissue ${ }^{120}$, and 3: activation of TLRs signaling pathway, including TLR2, TLR4, TLR5, and 
Table 1: Role of cytokines involved in regulation of liver fibrosis

\begin{tabular}{|c|c|c|}
\hline Mediators & Mechanism of action & Reference(s) \\
\hline \multicolumn{3}{|l|}{ Growth Factors } \\
\hline $\begin{array}{l}\text { Platelet-derived growth factor } \\
\text { (PDGF) }\end{array}$ & $\begin{array}{l}\text { Stimulates activation and proliferation of HSCs } \\
\text { Upregulates expression of TIMP-1 } \\
\text { Inhibits collagenase activity }\end{array}$ & $39,66-69$ \\
\hline $\begin{array}{l}\text { Transforming growth factor- } \beta \\
\text { (TGF- } \beta \text { ) }\end{array}$ & $\begin{array}{l}\text { Stimulates activation of HSCs } \\
\text { Upregulates type I collagen and } \alpha \text {-SMA synthesis } \\
\text { Promotes MFs survival through activation of FAK } \\
\text { Inhibits DNA synthesis and induces hepatocytes apoptosis } \\
\text { Upregulates expression of TIMPs } \\
\text { Increases LOXs production }\end{array}$ & $43,70-75$ \\
\hline \multicolumn{3}{|l|}{ Interleukins } \\
\hline Interleukin-1 (IL-1) & $\begin{array}{l}\text { Activates HSCs and promotes HSCs survival through NF- } \mathrm{kB} \\
\text { Promotes lipid accumulation in NAFLD } \\
\text { Promotes type I collagen synthesis } \\
\text { Upregulates TIMP-1 }\end{array}$ & $41,42,76-78$ \\
\hline $\begin{array}{l}\text { Tumor necrosis factor- } \alpha \\
(\text { TNF- } \alpha)\end{array}$ & $\begin{array}{l}\text { Promotes activation of HSCs and reduces apoptosis of activated HSCs } \\
\text { Upregulates TIMP-1 } \\
\text { Stimulates hepatocyte apoptosis }\end{array}$ & $77,79-83$ \\
\hline Interleukin-17 (IL-17) & $\begin{array}{l}\text { Upregulates type I collagen, TGF- } \beta \text {, and TNF- } \alpha \text { through STAT3 pathway } \\
\text { Promotes activation of HSCs }\end{array}$ & $84-86$ \\
\hline Interleukin-10 (IL-10) & $\begin{array}{l}\text { Inhibits HSCs activity } \\
\text { Inhibits expression of TIMP-1 and TGF- } \beta\end{array}$ & $87-89$ \\
\hline Interleukin-22 (IL-22) & Promotes HSCs senescence & 90,91 \\
\hline Interleukin-6 (IL-6) & $\begin{array}{l}\text { Attenuates hepatocytes apoptosis and induce regeneration of hepatocytes through } \\
\mathrm{NF}-\mathrm{kB} \\
\text { Induces insulin resistance }\end{array}$ & 92,93 \\
\hline \multicolumn{3}{|l|}{ Interferon } \\
\hline Interferon- $\alpha(\mathrm{IFN}-\alpha)$ & Has an anti-apoptotic effect on activated HSCs & 94 \\
\hline Interferon- $\beta$ (IFN- $\beta$ ) & $\begin{array}{l}\text { Inactivates HSCs and decrease production of type I collagen and } \alpha \text {-SMA through } \\
\text { inhibition of PDGF and TGF- } \beta\end{array}$ & $94-97$ \\
\hline Interferon- $\gamma($ IFN- $\gamma)$ & $\begin{array}{l}\text { Inhibits activation of HSCs and reduce type I collagen deposition } \\
\text { Induces hepatic HSCs apoptosis and cell cycle arrest }\end{array}$ & $95-97$ \\
\hline
\end{tabular}

\begin{tabular}{llc}
\hline Chemokine & & \\
\hline CCL2 & $\begin{array}{l}\text { Promotes migration of bone marrow-derived monocyte to liver } \\
\text { Activates HSCs } \\
\text { Induces insulin resistance in NAFLD }\end{array}$ & $98-103$ \\
\hline CXCL10 & $\begin{array}{l}\text { Promotes hepatocytes apoptosis } \\
\text { Inhibits NK cells-mediated HSCs inactivation } \\
\text { Stimulates T-cell chemotaxis to the liver }\end{array}$ & 104,105 \\
\hline CXCL16 & Promotes intrahepatic accumulation of NKT cells & 106 \\
\hline $\begin{array}{l}\text { HSC: hepatic stellate cell; NF-kB: nuclear factor-kB; NAFLD: non-alcoholic fatty liver disease; TIMP: tissue inhibitors of metalloproteinase; STAT: signal transducer and activator of transcrip- } \\
\text { tion; SMA: smoth muscle actin; NKT: natural killer T cell; FAK: focal adhesion kinase; LOX: lysyl oxidase; CXCL: chemokine (C-X-C motif) ligand; CCL: chemokine (C-C motif) ligand }\end{array}$
\end{tabular}

TLR9, in KCs and HSCs. As a result of downstream signaling pathways, KCs produce CCL2 that recruits
LY6Chi monocytes into the liver. LY6Chi monocytes produce IL-1 and TNF- $\alpha$ and intensify NASH-related 
fibrosis.$^{78,99,121,122}$

Studies in animal models have shown that in nonalcoholic steatohepatitis, hepatic stellate cells are increasingly activated. Moreover, association between decreased insulin sensitivity and advanced liver fibrosis in NAFLD, suggests that insulin resistance besides high fructose and sodium consumption play role in HSCs activation and development of fibrosis. ${ }^{123-125}$ Recently, it has been suggested that free cholesterol accumulation in HSCs as a consequence of Acylcoenzyme A: cholesterol acyltransferase 1 (ACAT1) deficiency enhances TLR4 signaling and liver fibrosis in the mouse model of NASH. ${ }^{126}$

\section{Diagnosis of liver fibrosis}

Defining the disease state is essential for deciding on therapeutic choices and predicting prognosis. Although liver biopsy is considered the standard reference for assessing liver fibrosis, it has important limitations including invasiveness ${ }^{127}$; hence, the need is growing for alternative accurate and noninvasive methods for diagnosis and staging of hepatic fibrosis. Over the last few decades, noninvasive approaches to diagnosis of liver fibrosis have been developed, which overcome some limitations of liver biopsy.

\section{Liver biopsy}

Apart from being invasive, liver biopsy has other limitations including sampling error as well as intra- and inter-observer variability. Since fibrosis is heterogeneous in distribution and samples taken by biopsy correspond to roughly $1 / 50,000$ of hepatic parenchymal mass, the tissue taken might not represent the major liver pathology. ${ }^{128}$

Based on the underlying fibrogenic factor, liver fibrosis could have diverse patterns, and thus histologic examination is important in distinguishing between different causes of liver fibrosis. Generally, histopathological assessments can show necroinflammatory activity (grade) and fibrosis stage of chronic hepatitis. There are different scoring systems for staging liver fibrosis such as METAVIR score, the most widely used scoring system for in- terpretation of fibrosis stage, histology activity index (HAI) proposed by Knodell in 1981, and modified HAI of Ishak et al. ${ }^{29-131}$

Recently pathologists have developed a new approach, named "morphometry", which can be used to quantify fibrosis by measurement of collagen proportional area (CPA). ${ }^{132,133}$ Though previous fibrosis scores are semi-quantitative and cannot be treated as linear values with statistical tests, CPA enables linear assessment of the amount of fibrosis. ${ }^{134}$

Immunohistochemical analysis of cellular markers such as cytokeratin 7 as a marker of ductular proliferation, $\alpha$-SMA as a marker of HSCs activation, and CD34 as a marker of LSEC capillarization provides functional and dynamic information about fibrogenesis. ${ }^{135,136}$

\section{Laboratory tests}

In search of noninvasive markers of fibrosis, a constellation of biochemical and hematological serum markers have been suggested as predictors of liver fibrosis. Serum markers of fibrosis are classified as direct and indirect markers. Direct biomarkers measure components of the hepatic ECM as well as the enzymes, which regulate the matrix; they include MMPs, subtypes of collagen, and hyaluronic acid among others. ${ }^{137,138}$ Indirect markers refer to parameters such as platelet count which might reflect hypersplenism due to portal hypertension, aspartate aminotransferase (AST) and alanine aminotransferase (ALT) as markers of liver cell inflammation, cytokeratin 18 as an indicator of hepatocyte apoptosis, and international normalized ratio (INR) as an index of hepatocyte malfunction. ${ }^{107,139}$ Various combinations of these markers are used in the diagnosis of hepatic fibrosis. ${ }^{140}$ Combination of serum markers with clinical findings and defining new measures may improve accuracy of liver fibrosis prediction. Some of these predictors are presented in table 2 .

\section{Imaging modalities}

Imaging diagnostic modalities, especially ultrasound (US), have played significant role in chronic 
Table 2: Selected biomarkers for assessment of liver fibrosis

\begin{tabular}{|c|c|c|}
\hline Biomarkers & Components & Reference(s) \\
\hline AST to Platelet Ratio Index (APRI) & AST/platelet count & 139 \\
\hline BARD score & BMI, AST/ALT ratio, diabetes & 141 \\
\hline Enhanced Liver Fibrosis Score (ELF) & $\begin{array}{l}\text { Age, hyaluronic acid, TIMP-1 level, N-terminal propeptide of type I } \\
\text { collagen }\end{array}$ & 142 \\
\hline FIB-4 & AST, ALT, age, platelet count & 143 \\
\hline Fibrometer & $\begin{array}{l}\text { Platelet count, prothrombin index, AST, } \alpha 2 \text {-macroglobulin, hyaluronate, } \\
\text { urea, age }\end{array}$ & 144 \\
\hline Fibrotest & $\begin{array}{l}\alpha 2 \text {-macroglobulin, haptoglobin, apolipoprotein } \mathrm{A} 1, \gamma \mathrm{GT} \text {, total bilirubin, } \\
\text { age, gender }\end{array}$ & 145 \\
\hline Hepascore & Bilirubin, $\alpha 2$-macroglobulin, hyaluronate, $\gamma \mathrm{GT}$, age, gender & 146 \\
\hline NAFLD Fibrosis Score (NFS) & Age, IFG/diabetes, BMI, platelet count, albumin, AST/ALT ratio & 147 \\
\hline
\end{tabular}

liver disease management. In addition to US, magnetic resonance imaging (MRI), computed tomography (CT), and other modalities derived from these basic methods have enabled accurate estimation of liver fibrosis and findings associated with portal hypertension.

Liver stiffness (LS) results from fibrotic tissue deposition and liver inflammation, which associates with staging of liver fibrosis. ${ }^{148}$ Liver stiffness can be measured by using principles of elastography, which are based on propagation of mechanical shear wave in tissues. Shear waves propagate more rapidly in stiffer tissue corresponding to advanced fibrosis. Here we review US- and MR-based LS measurement.

\section{US-based LS measurement: transient elastog-} raphy (TE)

Transient elastography (TE; Fibroscan), the first commercialized elastography technique, was introduced in 2003. ${ }^{149}$ Transient elastography calculates LS and displays the value as the median of 10 validated measurements in kilopascals $(\mathrm{kPa})$ and closely correlates with the stage of liver fibrosis. The technique is noninvasive, replicable, fast, and has high inter- and intra-observer repeatability; however it has limitations, including probable sampling errors, since it assesses approximately 1/100 liver parenchyma, confounding effect of a meal on its accuracy, and measurement failure in presence of ascites and severe obesity. Therefore, its accuracy decreases in patients with NAFLD many of whom are obese. ${ }^{150,151}$

MR-based LS measurement: magnetic resonance elastography (MRE)

Magnetic resonance elastography has been widely evaluated and demonstrated as a precise modality with high diagnostic performance for detection of advanced fibrosis. ${ }^{152}$ Recently, a meta-analysis by Singh et al, that included 12 retrospective studies, identified the area under receiver-operating curve (AUROC) value of MRE as 0.84 for diagnosis of any fibrosis (stage 1), 0.88 for significant fibrosis (stage 2), 0.93 for advanced fibrosis (stage 3), 0.92 for cirrhosis (stage 4), and the overall failure rate of MRE as 4.3\%.153 Moreover, three-dimensional (3D)-MRE, a newly emerging technique, has been introduced with higher diagnostic accuracy under some circumstances than two-dimensional (2D)MRE. ${ }^{154}$

MRE might be time consuming and expensive, but has the ability to analyze the entire liver tissue and is not affected by severe obesity and presence of ascites. ${ }^{155}$

\section{CONCLUSION}

New findings have revealed novel cellular and molecular pathways in the development of liver fibrosis. These achievements are the basic step in determination of biological targets and development of pharma- 
cologic agents to stop the process of fibrogenesis and reverse it towards less stages of liver fibrosis. As the concept of liver fibrosis reversibility becomes more at hand, there is a need for better diagnostic tools for evaluating the severity of liver fibrosis in order to evaluate the effectiveness of novel interventions. Advanced imaging techniques are being developed in this regard and there is much hope to see significant steps forward in the area of research on liver fibrosis in coming years.

\section{CONFLICT OF INTEREST}

The authors declare no conflict of interest related to this work.

\section{REFERENCES}

1. Bataller R, Brenner DA. Liver fibrosis. J Clin Invest 2005;115:209-18. doi:10.1172/JCI200524282DS1

2. Poynard T, Mathurin P, Lai CL, Guyader D, Poupon R, Tainturier $\mathrm{MH}$, et al. A comparison of fibrosis progression in chronic liver diseases. $J$ Hepatol 2003;38:257-65. doi: 10.1016/S0168-8278(02)00413-0

3. Schuppan D, Ruehl M, Somasundaram R, Hahn EG. Matrix as a modulator of hepatic fibrogenesis. Semin Liver Dis 2001;21:351-72. doi:10.1055/s-2001-17556

4. Bonis PA, Friedman SL, Kaplan MM. Is liver fibrosis reversible? $N$ Engl J Med 2001;344:452-4. doi: 10.1056/ NEJM200102083440610

5. Falize L, Guillygomarc'h A, Perrin M, Laine F, Guyader D, Brissot P, et al. Reversibility of hepatic fibrosis in treated genetic hemochromatosis: a study of 36 cases. Hepatology 2006;44:472-7. doi: 10.1002/hep.21260

6. Liaw YF. Reversal of cirrhosis: an achievable goal of hepatitis B antiviral therapy. J Hepatol 2013;59:880-1. doi: 10.1016/j.jhep.2013.05.007

7. Mallet V, Gilgenkrantz H, Serpaggi J, Verkarre V, Vallet-Pichard A, Fontaine $\mathrm{H}$, et al. Brief communication: the relationship of regression of cirrhosis to outcome in chronic hepatitis C. Ann Intern Med 2008;149:399-403. doi:10.7326/0003-4819-149-6-200809160-00006

8. Shen X, Cheng S, Peng Y, Song H, Li H. Attenuation of early liver fibrosis by herbal compound "Diwu Yanggan" through modulating the balance between epithelial-tomesenchymal transition and mesenchymal-to-epithelial transition. BMC Complement Altern Med 2014;14:418. doi: $10.1186 / 1472-6882-14-418$

9. Friedman SL. Mechanisms of hepatic fibrogenesis. Gastroenterology 2008;134:1655-69. doi:10.1053/j.gastro.2008.03.003

10. Tsochatzis EA, Bosch J, Burroughs AK. Liver cirrhosis. Lan- cet 2014;383:1749-61. doi: 10.1016/S0140-6736(14)60121-5

11. Bajaj JS, Wade JB, Gibson DP, Heuman DM, Thacker LR, Sterling RK, et al. The multi-dimensional burden of cirrhosis and hepatic encephalopathy on patients and caregivers. Am J Gastroenterol 2011;106:1646-53. doi:10.1038/ ajg.2011.157

12. Minino AM. Death in the United States, 2009. NCHS Data Brief 2011:1-8.

13. Global, regional, and national age-sex specific all-cause and cause-specific mortality for 240 causes of death, 19902013: a systematic analysis for the Global Burden of Disease Study 2013. Lancet 2015;385:117-71. doi: 10.1016/ S0140-6736(14)61682-2

14. Davis GL, Alter MJ, El-Serag H, Poynard T, Jennings LW. Aging of hepatitis $\mathrm{C}$ virus (HCV)-infected persons in the United States: a multiple cohort model of HCV prevalence and disease progression. Gastroenterology 2010;138:51321, 521.e511-16. doi: 10.1053/j.gastro.2009.09.067

15. Zezos P, Renner EL. Liver transplantation and nonalcoholic fatty liver disease. World $J$ Gastroenterol 2014;20:15532-38. doi: 10.3748/WJG.v20.i42.15532

16. Papastergiou V, Tsochatzis E, Burroughs AK. Non-invasive assessment of liver fibrosis. Ann Gastroenterol 2012;25:218-31.

17. Udompap P, Kim D, Kim WR. Current and Future Burden of Chronic Nonmalignant Liver Disease. Clin Gastroenterol Hepatol 2015;13:2031-41. doi: 10.1016/j.cgh.2015.08.015

18. Trautwein C, Friedman SL, Schuppan D, Pinzani M: Hepatic fibrosis: Concept to treatment. J Hepatol 2015;62:S1524. doi : http://dx.doi.org/10.1016/j.jhep.2015.02.039

19. Mederacke I, Hsu CC, Troeger JS, Huebener P, Mu X, Dapito DH, et al. Fate tracing reveals hepatic stellate cells as dominant contributors to liver fibrosis independent of its aetiology. Nat Commun 2013;4:2823. doi:10.1038/ ncomms 3823

20. Wells RG, Schwabe RF. Origin and function of myofibroblasts in the liver. Semin Liver Dis 2015;35:97-106. doi: 10.1055/s-0035-1550061

21. Parola M, Marra F, Pinzani M. Myofibroblast - like cells and liver fibrogenesis: Emerging concepts in a rapidly moving scenario. Mol Aspects Med 2008;29:58-66. doi:10.1016/j. mam.2007.09.002

22. Iwaisako $\mathrm{K}$, Jiang $\mathrm{C}$, Zhang $\mathrm{M}$, Cong M, Moore-Morris TJ, Park TJ, et al. Origin of myofibroblasts in the fibrotic liver in mice. Proc Natl Acad Sci U S A 2014;111:E3297305.

23. Dranoff JA, Wells RG Portal fibroblasts: Underappreciated mediators of biliary fibrosis. Hepatology 2010;51:1438-1444. doi: 10.1002/hep.23405

24. Kisseleva T, Uchinami H, Feirt N, Quintana-Bustamante O, Segovia JC, Schwabe RF, et al. Bone marrow-derived fibrocytes participate in pathogenesis of liver fibrosis. $J$ Hepatol 2006;45:429-38. doi: 10.1016/j.jhep.2006.04.014 
25. Scholten D, Reichart D, Paik YH, Lindert J, Bhattacharya $\mathrm{J}$, Glass CK, et al. Migration of fibrocytes in fibrogenic liver injury. Am J Pathol 2011;179:189-98. doi: 10.1016/j. ajpath.2011.03.049

26. Lemoinne S, Cadoret A, Rautou PE, El Mourabit H, Ratziu $\mathrm{V}$, Corpechot C, et al. Portal myofibroblasts promote vascular remodeling underlying cirrhosis formation through the release of microparticles. Hepatology 2015;61:10411055. doi: $10.1002 /$ hep. 27318

27. Kalluri R. EMT: when epithelial cells decide to become mesenchymal-like cells. J Clin Invest 2009;119:1417-19. doi:10.1172/JCI39675

28. Taura K, Miura K, Iwaisako K, Osterreicher CH, Kodama Y, Penz-Osterreicher M, Brenner DA Hepatocytes do not undergo epithelial-mesenchymal transition in liver fibrosis in mice. Hepatology 2010;51:1027-1036. doi : 10.1002/hep.23368

29. Scholten D, Osterreicher CH, Scholten A, Iwaisako K, $\mathrm{Gu} \mathrm{G}$, Brenner DA, et al. Genetic labeling does not detect epithelial-to-mesenchymal transition of cholangiocytes in liver fibrosis in mice. Gastroenterology 2010; 139:987998. doi : 10.1053/j.gastro.2010.05.005

30. Chu AS, Diaz R, Hui JJ, Yanger K, Zong Y, Alpini G, et al. Lineage tracing demonstrates no evidence of cholangiocyte epithelial-to-mesenchymal transition in murine models of hepatic fibrosis. Hepatology 2011;53:1685-95. doi: 10.1002/hep. 24206

31. Geerts A. History, heterogeneity, developmental biology, and functions of quiescent hepatic stellate cells. Semin Liver Dis 2001;21:311-335.

32. Wake K. Perisinusoidal stellate cells (fat-storing cells, interstitial cells, lipocytes), their related structure in and around the liver sinusoids, and vitamin A-storing cells in extrahepatic organs. Int Rev Cytol 1980;66:303-53. doi:10.1016/S0074-7696(08)61977-4

33. Blomhoff R, Wake K. Perisinusoidal stellate cells of the liver: important roles in retinol metabolism and fibrosis. Faseb j 1991;5:271-7.

34. Tennakoon AH, Izawa T, Wijesundera KK, Golbar HM, Tanaka M, Ichikawa C, et al. Characterization of glial fibrillary acidic protein (GFAP)-expressing hepatic stellate cells and myofibroblasts in thioacetamide (TAA)-induced rat liver injury. Exp Toxicol Pathol 2013;65:1159-71. doi:10.1016/j.etp.2013.05.008

35. Carotti S, Morini S, Corradini SG, Burza MA, Molinaro A, Carpino G, et al. Glial fibrillary acidic protein as an early marker of hepatic stellate cell activation in chronic and posttransplant recurrent hepatitis C. Liver Transpl 2008;14:806-14. doi:10.1002/1t.21436

36. Lua I, James D, Wang J, Wang KS, Asahina K. Mesodermal mesenchymal cells give rise to myofibroblasts, but not epithelial cells, in mouse liver injury. Hepatology 2014;60:311-22. doi: 10.1002/hep.27035

37. Baertschiger RM, Serre-Beinier V, Morel P, Bosco D, Peyrou M, Clement S, et al. Fibrogenic potential of human multipotent mesenchymal stromal cells in injured liver. PLOS
One 2009;4:e6657. doi: 10.1371/journal.pone.0006657

38. Niki T, Pekny M, Hellemans K, Bleser PD, Berg KV, Vaeyens $\mathrm{F}$, et al. Class VI intermediate filament protein nestin is induced during activation of rat hepatic stellate cells. Hepatology 1999;29:520-7.

39. Kocabayoglu P, Lade A, Lee YA, Dragomir AC, Sun X, Fiel MI, et al. beta-PDGF receptor expressed by hepatic stellate cells regulates fibrosis in murine liver injury, but not carcinogenesis. J Hepatol 2015;63:141-7. doi:10.1016/j. jhep.2015.01.036

40. Lee JI, Wright JH, Johnson MM, Bauer RL, Sorg K, Yuen $\mathrm{S}$, et al. Role of Smad3 in Platelet-Derived Growth FactorC induced liver fibrosis. Am J Physiol Cell Physiol 2016 15;310:C436-45. doi: 10.1152/ajpcell.00423.2014.

41. Yaping Z, Ying W, Luqin D, Ning T, Xuemei A, Xixian Y. Mechanism of interleukin-1beta-induced proliferation in rat hepatic stellate cells from different levels of signal transduction. APMIS 2014;122:392-8. doi: 10.1111/ apm.12155.

42. Zhang Y, Yao X Role of c-Jun N-terminal kinase and p38/ activation protein-1 in interleukin-1beta-mediated type I collagen synthesis in rat hepatic stellate cells. Apmis 2012;120:101-7.

43. Li HY, Ju D, Zhang DW, Li H, Kong LM, Guo Y, et al Activation of TGF-beta1-CD147 positive feedback loop in hepatic stellate cells promotes liver fibrosis. Sci Rep 2015;5:16552. doi: 10.1038/srep16552.

44. Hong IH, Park SJ, Goo MJ, Lee HR, Park JK, Ki MR, et al. JNK1 and JNK2 regulate alpha-SMA in hepatic stellate cells during $\mathrm{CCl} 4$-induced fibrosis in the rat liver. Pathol Int 2013;63:483-91. dio : 10.1111/pin.12094

45. Schmitt-Graff A, Kruger S, Bochard F, Gabbiani G, Denk H. Modulation of alpha smooth muscle actin and desmin expression in perisinusoidal cells of normal and diseased human livers. Am J Pathol 1991;138:1233-42.

46. Farrell GC, Larter CZ, Hou JY, Zhang RH, Yeh MM, Williams $\mathrm{J}$, et al. Apoptosis in experimental NASH is associated with p53 activation and TRAIL receptor expression. $J$ Gastroenterol Hepatol 2009;24:443-52.

47. Feldstein AE, Canbay A, Angulo P, Taniai M, Burgart LJ, Lindor KD, et al. Hepatocyte apoptosis and fas expression are prominent features of human nonalcoholic steatohepatitis. Gastroenterology 2003;125:437-43. doi: 10.1016/ S0016-5085(03)00907-7

48. Canbay A, Taimr P, Torok N, Higuchi H, Friedman S, Gores GJ. Apoptotic body engulfment by a human stellate cell line is profibrogenic. Lab Invest 2003;83:655-63.

49. Zhan SS, Jiang JX, Wu J, Halsted C, Friedman SL, Zern MA, et al. Phagocytosis of apoptotic bodies by hepatic stellate cells induces NADPH oxidase and is associated with liver fibrosis in vivo. Hepatology 2006;43:435-43.

50. Watanabe A, Hashmi A, Gomes DA, Town T, Badou A, Flavell RA, et al. Apoptotic hepatocyte DNA inhibits hepatic stellate cell chemotaxis via toll-like receptor 9. Нера- 
tology 2007;46:1509-18. doi: 10.1002/hep. 21867

51. Guicciardi ME, Gores GJ. Apoptosis as a mechanism for liver disease progression. Semin Liver Dis 2010;30:402-10.

52. Jiang JX, Mikami K, Venugopal S, Li Y, Torok NJ Apoptotic body engulfment by hepatic stellate cells promotes their survival by the JAK/STAT and Akt/NF-kappaBdependent pathways. J Hepatol 2009;51:139-148. doi 10.1016/j.jhep.2009.03.024

53. Jeong WI, Do SH, Yun HS, Song BJ, Kim SJ, Kwak WJ, et al. Hypoxia potentiates transforming growth factor-beta expression of hepatocyte during the cirrhotic condition in rat liver. Liver Int 2004;24:658-68.

54. Wiemann SU, Satyanarayana A, Tsahuridu M, Tillmann HL, Zender L, Klempnauer J, et al. Hepatocyte telomere shortening and senescence are general markers of human liver cirrhosis. Faseb j 2002;16:935-42.

55. Rudolph KL, Chang S, Millard M, Schreiber-Agus N, DePinho RA. Inhibition of experimental liver cirrhosis in mice by telomerase gene delivery. Science 2000;287:12538. doi : $10.1126 /$ science.287.5456.1253

56. Yokomori H, Oda M, Yoshimura K, Hibi T. Recent advances in liver sinusoidal endothelial ultrastructure and fine structure immunocytochemistry. Micron 2012;43:129-34. doi:10.1016/j.micron.2011.08.002

57. Deleve LD, Wang X, Guo Y. Sinusoidal endothelial cells prevent rat stellate cell activation and promote reversion to quiescence. Hepatology 2008;48:920-30. doi: 10.1002/ hep. 22351

58. Mori T, Okanoue T, Sawa Y, Hori N, Ohta M, Kagawa $\mathrm{K}$. Defenestration of the sinusoidal endothelial cell in a rat model of cirrhosis. Hepatology 1993;17:891-7. doi: 10.1002/hep. 1840170520

59. DeLeve LD. Liver sinusoidal endothelial cells in hepatic fibrosis. Hepatology 2015;61:1740-46. doi: 10.1002/ hep. 27376

60. Xie G, Wang X, Wang L, Atkinson RD, Kanel GC, Gaarde WA, et al. Role of differentiation of liver sinusoidal endothelial cells in progression and regression of hepatic fibrosis in rats. Gastroenterology 2012;142:918-27.e916. doi : 10.1053/j.gastro.2011.12.017

61. Bilzer M, Roggel F, Gerbes AL. Role of kupffer cells in host defense and liver disease. Liver Int 2006;26:1175-86. doi: 10.1111/j.1478-3231.2006.01342.x

62. Xidakis C, Ljumovic D, Manousou P, Notas G, Valatas V, Kolios G, et al. Production of pro- and anti-fibrotic agents by rat Kupffer cells; the effect of octreotide. Dig Dis Sci 2005;50:935-41. doi : 10.1007/s10620-005-2668-8

63. Matsuoka M, Tsukamoto H. Stimulation of hepatic lipocyte collagen production by kupffer cell-derived transforming growth factor beta: implication for a pathogenetic role in alcoholic liver fibrogenesis. Hepatology 1990;11:599-605. doi: 10.1002/hep. 1840110412

64. Luckey SW, Petersen DR. Activation of Kupffer cells during the course of carbon tetrachloride-induced liver in- jury and fibrosis in rats. Exp Mol Pathol 2001;71:226-40. doi:10.1006/exmp.2001.2399

65. Canbay A, Feldstein AE, Higuchi $\mathrm{H}$, Werneburg $\mathrm{N}$, Grambihler A, Bronk SF, et al. Kupffer cell engulfment of apoptotic bodies stimulates death ligand and cytokine expression. Hepatology 2003;38:1188-98. doi: 10.1053/ jhep.2003.50472

66. Czochra P, Klopcic B, Meyer E, Herkel J, Garcia-lazaro $\mathrm{JF}$, Thieringer $\mathrm{F}$, et al. Liver fibrosis induced by hepatic overexpression of pdgf-b in transgenic mice. J Hepatol 2006;45:419-28.

67. Borkham-Kamphorst E, Alexi P, Tihaa L, Haas U, Weiskirchen R. Platelet-derived growth factor-D modulates extracellular matrix homeostasis and remodeling through TIMP-1 induction and attenuation of MMP-2 and MMP-9 gelatinase activities. Biochem Biophys Res Commun 2015;457:307-13. doi:10.1016/j.bbrc.2014.12.106

68. Breitkopf K, Roeyen C, Sawitza I, Wickert L, Floege J, Gressner AM. Expression patterns of PDGF-A, -B, -C and -D and the PDGF-receptors alpha and beta in activated rat hepatic stellate cells (HSC). Cytokine 2005;31:349-57. doi:10.1016/j.cyto.2005.06.005

69. Martin IV, Borkham-kamphorst E, Zok S, Van roeyen CR, Eriksson U, Boor P, et al. Platelet-derived growth factor (pdgf)-c neutralization reveals differential roles of pdgf receptors in liver and kidney fibrosis. am $j$ pathol 2013;182:107-17. doi: 10.1016/j.ajpath.2012.09.006

70. Wells RG, Kruglov E, Dranoff JA. Autocrine release of TGF- $\beta$ by portal fibroblasts regulates cell growth. FEBS Lett 2004;559:107-10. doi: 10.1016/S0014-5793(04)00037-7

71. Verrecchia F, Chu ML, Mauviel A. Identification of novel TGF-beta /Smad gene targets in dermal fibroblasts using a combined cDNA microarray/promoter transactivation approach. J Biol Chem 2001;276:17058-62. doi: 10.1074/ jbc.M100754200

72. Hellerbrand C, Stefanovic B, Giordano F, Burchardt ER, Brenner DA. The role of tgfbetal in initiating hepatic stellate cell activation in vivo. $J$ Hepatol 1999;30:77-87. doi : 10.1016/s0168-8278(99)80010-5

73. Horowitz JC, Rogers DS, Sharma V, Vittal R, White ES, Cui Z, et al. Combinatorial activation of FAK and AKT by transforming growth factor-betal confers an anoikis-resistant phenotype to myofibroblasts. Cell Signal 2007;19:76171. doi:10.1016/j.cellsig.2006.10.001

74. Chen WB, Lai SS, Yu DC, Liu J, Jiang S, Zhao DD, et al. GGPPS deficiency aggravates CCl4-induced liver injury by inducing hepatocyte apoptosis. FEBS Lett 2015;589:111926. doi: 10.1016/j.febslet.2015.03.015

75. Iwasaki A, Sakai K, Moriya K, Sasaki T, Keene DR, Akhtar $\mathrm{R}$, et al. Molecular Mechanism Responsible for Fibronectin-controlled Alterations in Matrix Stiffness in Advanced Chronic Liver Fibrogenesis. J Biol Chem 2016;291:72-88. doi: 10.1074/jbc.M115.691519

76. Gieling RG, Wallace K, Han YP. Interleukin-1 participates in the progression from liver injury to fibrosis. $\mathrm{Am} \mathrm{J}$ 
Physiol Gastrointest Liver Physiol 2009;296: 1324-31. doi : 10.1152/ajpgi.90564.2008

77. Pradere JP, Kluwe J, De Minicis S, Jiao JJ, Gwak GY, Dapito DH, et al. Hepatic macrophages but not dendritic cells contribute to liver fibrosis by promoting the survival of activated hepatic stellate cells in mice. Hepatology 2013;58:1461-73. doi: 10.1002/hep.26429

78. Miura K, Kodama Y, Inokuchi S, Schnabl B, Aoyama T, Ohnishi H, et al. Toll-Like Receptor 9 Promotes Steatohepatitis by Induction of Interleukin-1\&\#x3b2; in Mice. Gastroenterology 2010;139:323-334.e27. doi:10.1053/j.gastro.2010.03.052

79. Connolly MK, Bedrosian AS, Mallen-St Clair J, Mitchell AP, Ibrahim J, Stroud A, et al. In liver fibrosis, dendritic cells govern hepatic inflammation in mice via TNF-alpha. J Clin Invest 2009;119:3213-25. doi:10.1172/JCI37581.

80. Kong F, You H, Zhao J, Liu W, Hu L, Luo W, et al. The enhanced expression of death receptor $5(\mathrm{dr} 5)$ mediated by hbv x protein through nf-kappab pathway is associated with cell apoptosis induced by (tnf- $\alpha$ related apoptosis inducing ligand) trail in hepatoma cells. Virol J 2015;12:1-9. doi : 10.1186/s12985-015-0416-Z

81. Osawa Y, Hoshi M, Yasuda I, Saibara T, Moriwaki H, Kozawa O. Tumor Necrosis Factor-? Promotes Cholestasis-Induced Liver Fibrosis in the Mouse through Tissue Inhibitor of Metalloproteinase-1 Production in Hepatic Stellate Cells. PLoS One 2013;8:e65251. doi : 10.1371/journal.pone.0065251

82. Saile B, Matthes N, Knittel T, Ramadori G. Transforming growth factor beta and tumor necrosis factor alpha inhibit both apoptosis and proliferation of activated rat hepatic stellate cells. Hepatology 1999;30:196-202. doi: 10.1002/ hep. 510300144

83. Saitou Y, Shiraki K, Fuke H, Inoue T, Miyashita K, Yamanaka Y,et al. Involvement of tumor necrosis factorrelated apoptosis-inducing ligand and tumor necrosis factor-related apoptosis-inducing ligand receptors in viral hepatic diseases.Hum Pathol 2005;36:1066-73. doi: 10.1016/j.humpath.2005.07.019

84. Hara M, Kono H, Furuya S, Hirayama K, Tsuchiya M, Fujii H. Interleukin-17A plays a pivotal role in cholestatic liver fibrosis in mice. J Surg Res 2013;183:574-82. doi: 10.1016/j.jss.2013.03.025

85. Meng F, Wang K, Aoyama T, Grivennikov SI, Paik Y, Scholten D, et al. Interleukin-17 Signaling in Inflammatory, Kupffer Cells, and Hepatic Stellate Cells Exacerbates Liver Fibrosis in Mice. Gastroenterology 2012;143:76576.e763. doi: 10.1053/j.gastro.2012.05.049

86. Tan Z, Qian X, Jiang R, Liu Q, Wang Y, Chen C, et al. IL-17A plays a critical role in the pathogenesis of liver fibrosis through hepatic stellate cell activation. J Immunol 2013;191:1835-44. doi: 10.4049/jimmunol.1203013

87. Chou WY, Lu CN, Lee TH, Wu CL, Hung KS, Concejero $\mathrm{AM}$, et al. Electroporative interleukin-10 gene transfer ameliorates carbon tetrachloride-induced murine liver fibrosis by MMP and TIMP modulation. Acta Pharmacol Sin
2006;27:469-76. doi:10.1111/j.1745-7254.2006.00304.x

88. Huang YH, Shi MN, Zheng WD, Zhang LJ, Chen ZX, Wang XZ. Therapeutic effect of interleukin-10 on ccl4induced hepatic fibrosis in rats. World $J$ Gastroenterol 2006;12:1386-91.

89. Zhang LJ, Zheng WD, Chen YX, Huang YH, Chen ZX, Zhang SJ, et al. Antifibrotic effects of interleukin-10 on experimental hepatic fibrosis. Hepatogastroenterology 2007;54:2092-98.

90. Kong X, Feng D, Mathews S, Gao B. Hepatoprotective and anti-fibrotic functions of interleukin-22: therapeutic potential for the treatment of alcoholic liver disease. $J$ Gastroenterol Hepatol 2013;28 Suppl 1:56-60. doi: 10.1111/ jgh. 12032

91. Kong X, Feng D, Wang H, Hong F, Bertola A, Wang FS, et al. Interleukin-22 induces hepatic stellate cell senescence and restricts liver fibrosis in mice. Hepatology 2012;56:1150-9. doi: 10.1002/hep.25744

92. Klover PJ, Zimmers TA, Koniaris LG, Mooney RA. Chronic exposure to interleukin-6 causes hepatic insulin resistance in mice. Diabetes 2003;52:2784-9. doi: 10.2337/ diabetes.52.11.2784

93. Kovalovich K, DeAngelis RA, Li W, Furth EE, Ciliberto $\mathrm{G}$, Taub R. Increased toxin-induced liver injury and fibrosis in interleukin-6-deficient mice. Hepatology 2000;31:14959. doi: 10.1002/hep.510310123

94. Rao HY, Wei L, Wang JH, Fei R, Jiang D, Zhang Q, et al. Inhibitory effect of human interferon-beta-1a on activated rat and human hepatic stellate cells. J Gastroenterol Hepatol 2010;25:1777-84. doi: 10.1111/j.1440-1746.2010.06264.x

95. Baroni GS, D'Ambrosio L, Curto P, Casini A, Mancini R, Jezequel AM, et al. Interferon gamma decreases hepatic stellate cell activation and extracellular matrix deposition in rat liver fibrosis. Hepatology 1996;23:1189-99. doi: 10.1002/hep.510230538

96. Jeong WI, Park O, Radaeva S, Gao B. STAT1 inhibits liver fibrosis in mice by inhibiting stellate cell proliferation and stimulating NK cell cytotoxicity. Hepatology 2006;44:1441-51. doi: 10.1002/hep.21419

97. Saile B, Eisenbach C, Dudas J, El-Armouche H, Ramadori G. Interferon-gamma acts proapoptotic on hepatic stellate cells (HSC) and abrogates the antiapoptotic effect of interferon-alpha by an HSP70-dependant pathway. Eur $J$ Cell Biol 2004;83:469-76. doi:10.1078/0171-9335-00409

98. Dambach DM, Watson LM, Gray KR, Durham SK, Laskin DL. Role of CCR2 in macrophage migration into the liver during acetaminophen-induced hepatotoxicity in the mouse. Hepatology 2002;35:1093-103. doi: 10.1053/ jhep.2002.33162

99. Miura K, Yang L, van Rooijen N, Ohnishi H, Seki E. Hepatic recruitment of macrophages promotes nonalcoholic steatohepatitis through CCR2. Am J Physiol Gastrointest Liver Physiol. 2012;302:G1310-1321. doi: 10.1152/ajpgi.00365.2011 
100. Sartipy P, Loskutoff DJ. Monocyte chemoattractant protein 1 in obesity and insulin resistance. Proc Natl Acad Sci USA 2003;100:7265-70. doi: 10.1073/pnas. 1133870100

101. Tateya S, Tamori Y, Kawaguchi T, Kanda H, Kasuga M. An increase in the circulating concentration of monocyte chemoattractant protein-1 elicits systemic insulin resistance irrespective of adipose tissue inflammation in mice. Endocrinology 2010;151:971-79. doi: 10.1210/en.2009-0926

102. Seki E, De minicis S, Inokuchi S, Taura K, Miyai K, Van rooijen $\mathrm{N}$, et al. $\mathrm{Ccr} 2$ promotes hepatic fibrosis in mice. Hepatology (baltimore, md) 2009;50:185-97. doi: 10.1002/ hep. 22952

103. Baeck C, Wei X, Bartneck M, Fech V, Heymann F, Gassler $\mathrm{N}$, et al. Pharmacological inhibition of the chemokine $\mathrm{C}-\mathrm{C}$ motif chemokine ligand 2 (monocyte chemoattractant protein 1) accelerates liver fibrosis regression by suppressing Ly-6C+ macrophage infiltration in mice. Hepatology 2014;59:1060-1072. doi: 10.1002/hep.26783

104. Oo YH, Banz V, Kavanagh D, Liaskou E, Withers DR, Humphreys E, et al. CXCR3-dependent recruitment and CCR6-mediated positioning of Th-17 cells in the inflamed liver. J Hepatol 2012;57:1044-51. doi: 10.1016/j. jhep.2012.07.008

105. Sahin H, Borkham-Kamphorst E, do ON NT, Berres ML, Kaldenbach M, Schmitz P, et al. Proapoptotic effects of the chemokine, CXCL 10 are mediated by the noncognate receptor TLR4 in hepatocytes. Hepatology 2013;57:797-805. doi: 10.1002/hep.26069

106. Wehr A, Baeck C, Heymann F, Niemietz PM, Hammerich L, Martin C, et al. Chemokine receptor CXCR6-dependent hepatic NK T Cell accumulation promotes inflammation and liver fibrosis. J Immunol 2013;190:5226-36. doi: 10.4049/jimmunol.1202909

107. Rosso C, Caviglia GP, Abate ML, Vanni E, Mezzabotta L, Touscoz GA, et al. Cytokeratin 18-Aspartate396 apoptotic fragment for fibrosis detection in patients with nonalcoholic fatty liver disease and chronic viral hepatitis. Dig Liver Dis 2016;48:55-61. doi: 10.1016/j.dld.2015.09.008

108. Cheong JY, Kim DJ, Hwang SG, Yang JM, Kim YB, Park $\mathrm{YN}$, et al. Serum markers for necroinflammatory activity in patients with chronic viral hepatitis and normal or mildly elevated aminotransferase levels. Lliver Int 2011;31:13528. doi: 10.1111/j.1478-3231.2011.02570.x

109. Martin-vilchez S, Sanz-cameno P, Rodriguez-munoz Y, Majano PL, Molina-jimenez F, Lopez-cabrera M, et al. The hepatitis $\mathrm{B}$ virus $\mathrm{x}$ protein induces paracrine activation of human hepatic stellate cells. Hepatology 2008;47:1872-83. doi: 10.1002/hep.22265

110. Gong G, Waris G, Tanveer R, Siddiqui A. Human hepatitis $C$ virus ns5a protein alters intracellular calcium levels, induces oxidative stress, and activates stat-3 and nf-kappa b. Proc Natl Acad Sci U S A 2001;98:9599-9604. doi: 10.1073/pnas. 171311298

111. Marshall A, Rushbrook S, Davies SE, Morris LS, Scott IS, Vowler SL, et al. Relation between hepatocyte G1 arrest, impaired hepatic regeneration, and fibrosis in chronic hepatitis C virus infection. Gastroenterology 2005;128:33-42. doi: 10.1053/j.gastro.2004.09.076

112. Petrasek J, Bala S, Csak T, Lippai D, Kodys K, Menashy V, et al. IL-1 receptor antagonist ameliorates inflammasomedependent alcoholic steatohepatitis in mice. J Clin Invest 2012;122:3476-89. doi:10.1172/JCI60777.

113. Lívero ARF,Acco A. Molecular basis of alcoholic fatty liver disease: from incidence to treatment. Hepatol Res 2016;46:111-23. doi:10.1111/hepr.12594

114. Hirano T, Kaplowitz N, Tsukamoto H, Kamimura S, Fernandez-checa JC. Hepatic mitochondrial glutathione depletion and progression of experimental alcoholic liver disease in rats. Hepatology 1992;16:1423-7. doi: 10.1002/ hep. 1840160619

115. Fernandez-checa JC, Kaplowitz N, Garcia-ruiz C, Colell A. Mitochondrial glutathione: importance and transport. Semin Liver Dis 1998;18:389-401. doi: 10.1055/s-20071007172

116. Vidali M, Stewart SF, Albano E. Interplay between oxidative stress and immunity in the progression of alcohol-mediated liver injury. Trends Mol Med 2008;14:63-71. doi: 10.1016/j.molmed.2007.12.005

117. Gao B, Bataller R. Alcoholic liver disease: pathogenesis and new therapeutic targets. Gastroenterology 2011;141:157285. doi: 10.1053/j.gastro.2011.09.002

118. Ouyang Y, Guo J, Lin C, Lin J, Cao Y, Zhang Y, et al. Transcriptomic analysis of the effects of Toll-like receptor 4 and its ligands on the gene expression network of hepatic stellate cells. Fibrogenesis Tissue Repair 2016;9:2. doi: 10.1186/s13069-016-0039-z

119. Day CP, James OF. Steatohepatitis: a tale of two "hits"? Gastroenterology 1998;114:842-5. doi: 10.1016/S00165085(98)70599-2

120. Cusi K. Role of obesity and lipotoxicity in the development of nonalcoholic steatohepatitis: pathophysiology and clinical implications. Gastroenterology 2012;142:711-725. e716. doi: 10.1053 /j.gastro.2012.02.003

121. Szabo G, Velayudham A, Romics L, Jr., Mandrekar P. Modulation of non-alcoholic steatohepatitis by pattern recognition receptors in mice: the role of toll-like receptors 2 and 4. Alcohol Clin Exp Res 2005;29:140s-45s. doi: 10.1097/01.alc.0000189287.83544.33

122. Baeck C, Wehr A, Karlmark KR, Heymann F, Vucur M, Gassler N, et al. Pharmacological inhibition of the chemokine CCL2 (MCP-1) diminishes liver macrophage infiltration and steatohepatitis in chronic hepatic injury. Gut 2012;61:416-26. doi:10.1136/gutjnl-2011-300304

123. Bugianesi E, Manzini P, D'antico S, Vanni E, Longo $\mathrm{F}$,Leone $\mathrm{N}$, et al. relative contribution of iron burden, hfe mutations, and insulin resistance to fibrosis in nonalcoholic fatty liver. Hepatology 2004;39:179-87. doi: 10.1002/ hep.20023

124. Softic S, Cohen DE, Kahn CR. Role of Dietary Fructose and 
Hepatic De Novo Lipogenesis in Fatty Liver Disease. Dig Dis Sci 2016;61:1282-93. doi: 10.1007/s10620-016-4054-0.

125. Huh JH, Lee KJ, Lim JS, Lee MY, Park HJ, Kim MY, et al. High Dietary Sodium Intake Assessed by Estimated 24-h Urinary Sodium Excretion Is Associated with NAFLD and Hepatic Fibrosis. PLoS One 2015;10:e0143222. doi: 10.1371/journal.pone.0143222

126. Tomita K, Teratani T, Suzuki T, Shimizu M, Sato H, Narimatsu K, et al. Acyl-CoA:cholesterol acyltransferase 1 mediates liver fibrosis by regulating free cholesterol accumulation in hepatic stellate cells. J Hepatol 2014;61:98-106. doi: $10.1016 /$ j.jhep.2014.03.018

127. Bravo AA, ShethSg, Chopra s. liver biopsy. N Engl J Med 2001;344:495-500.doi: 10.1056/NEJM200102153440706

128. Afdhal NH, Nunes D. Evaluation of liver fibrosis: a concise review. Am J Gastroenterol 2004;99:1160-74. doi:10.1111/ j.1572-0241.2004.30110.x

129. Bedossa P, Poynard T. An algorithm for the grading of activity in chronic hepatitis c. the metavir cooperative study group. Hepatology 1996;24:289-93. doi: 10.1002/ hep.510240201

130. Knodell RG, Ishak KG, Black WC, Chen TS, Craig R, Kaplowitz N, et al. Formulation and application of a numerical scoring system for assessing histological activity in asymptomatic chronic active hepatitis. Hepatology 1981;1:431-5. doi: 10.1016/S0168-8278(03)00005-9

131. Ishak K, Baptista A, Bianchi I,Callea F, De groote J, Gudat $\mathrm{F}$, et al. Histological grading and staging of chronic hepatitis. J Hepatol 1995;22:696-9. doi: 10.1016/01688278(95)80226-6

132. Calvaruso V, Burroughs AK, Standish R, Manousou P, Grillo F, Leandro G, et al. Computer-assisted image analysis of liver collagen: relationship to ishak scoring and hepatic venous pressure gradient. Hepatology 2009;49:123644. doi: $10.1002 /$ hep. 22745

133. Giannakeas N, Tsipouras MG, Tzallas AT, Kyriakidi K, Tsianou ZE, Manousou P, et al. A clustering based method for collagen proportional area extraction in liver biopsy images. Conf Proc Ieee Eng Med Biol Soc 2015;2015:30973100. doi : 10.1109/EMBC.2015.7319047

134. Goodman ZD, Becker RL, Pockros PJ, Afdhal NH. Progression of fibrosis in advanced chronic hepatitis c: evaluation by morphometric image analysis. Hepatology 2007;45:886-94. doi: 10.1002/hep.21595

135. Hu DD, Habib S, Li XM, Wang TL, Wang BE, Zhao XY. Angiogenesis: a new surrogate histopathological marker is capable of differentiating between mild and significant portal hypertension. Histol Histopathol 2015;30:205-12.

136. D'ambrosio R, Aghemo A, Rumi MG, Ronchi G, Donato MF, Paradis V, et al. A morphometric and immunohistochemical study to assess the benefit of a sustained virological response in hepatitis $\mathrm{c}$ virus patients with cirrhosis. Hepatology 2012;56:532-43. doi: 10.1002/hep.25606

137. Neuman MG, Cohen IB, Nanau RM. Hyaluronic acid as a non-invasive biomarker of liver fibrosis. Clin Biochem 2016;49:302-15. doi: 10.1016/j.clinbiochem.2015.07.019

138. Walsh KM, Timms P, Campbell S, Macsween RN, Morris AJ. Plasma levels of matrix metalloproteinase-2 (mmp-2) and tissue inhibitors of metalloproteinases -1 and -2 (timp1 and timp-2) as noninvasive markers of liver disease in chronic hepatitis c: comparison using roc analysis. Dig Dis Sci 1999;44:624-30.

139. Wai ET, Greenson JK, Fontana RJ, Kalbfleisch JD, Marrero JA, Conjeevaram HS, et al. A simple noninvasive index can predict both significant fibrosis and cirrhosis in patients with chronic hepatitis c. Hepatology 2003;38:518-26.

140. Jamali R, Arj A, Razavizade M, Aarabi MH. Prediction of nonalcoholic fatty liver disease via a novel panel of serum adipokines. Medicine (baltimore) 2016;95:e2630. doi: 10.1097/ MD.0000000000002630

141. Harrison SA, Oliver D, Arnold HL, Gogia S, Neuschwandertetri BA. Development and validation of a simple nafld clinical scoring system for identifying patients without advanced disease. Gut 2008;57:1441-7. doi:10.1136/gut.2007.146019

142. Rosenberg WM, Voelker M, Thiel R, Becka M, Burt A, Schuppan D, et al.: Serum markers detect the presence of liver fibrosis: a cohort study. Gastroenterology 2004;127:170413. doi: $10.1053 /$ j.gastro.2004.08.052

143. Sterling RK, Lissen E, Clumeck N, Sola R, Correa MC, Montaner J, et al: Development of a simple noninvasive index to predict significant fibrosis in patients with hiv/hov coinfection. Hepatology 2006;43:1317-25. doi: 10.1002/hep.21178

144. Cales P, Oberti F, Michalak S, Hubert-fouchard I, Rousselet $\mathrm{MC}$, Konate A, et al. A novel panel of blood markers to assess the degree of liver fibrosis. Hepatology 2005; 42 : 1373 81. doi: $10.1002 /$ hep. 20935

145. Imbert-bismut F, Ratziu V, Pieroni L, Charlotte F, Benhamou Y, Poynard T. Biochemical markers of liver fibrosis in patients with hepatitis c virus infection: a prospective study. Lancet 2001;357:1069-75. doi: 10.1016/S0140-6736(00)04258-6

146. Adams LA, Bulsara M, Rossi E, Deboer B, Speers D, George J, et al. Hepascore: an accurate validated predictor of liver fibrosis in chronic hepatitis c infection. Clin Chem 2005;51:1867-73.

147. Angulo P, Hui JM, Marchesini G, Bugianesi E, George J, Farrell GC, et al. The nafld fibrosis score: a noninvasive system that identifies liver fibrosis in patients with nafld. Hepatology 2007;45:846-54. doi: 10.1002/hep.21496

148. Lu Q, Lu C, Li J, Ling W, 1i X, He D, et al. Stiffness value and serum biomarkers in liver fibrosis staging: study in large surgical specimens in patients with chronic hepatitis $b$. Radiology 2016:151229. doi: 10.1148/radiol.2016151229

149. Sandrin L, Fourquet B, Hasquenoph JM, Yon S, Fournier $\mathrm{C}$, Mal F, et al. Transient elastography: a new noninvasive method for assessment of hepatic fibrosis. Ultrasound Med Biol 2003;29:1705-13. doi: 10.1016/j.ultrasmedbio.2003.07.001

150. Castera L, FoucherJ, Bernard PH, Carvalho F, Allaix D, 
Merrouche W, et al. Pitfalls of liver stiffness measurement: a 5-year prospective study of 13,369 examinations. Hepatology 2010;51:828-35. doi: 10.1002/hep.23425

151. Arena U, Lupsor platon M, Stasi C, Moscarella S, Assarat A, Bedogni G, et al. Liver stiffness is influenced by a standardized meal in patients with chronic hepatitis c virus at different stages of fibrotic evolution. Hepatology 2013;58:65-72. doi: 10.1002/hep.26343

152. Yoon JH, Lee JM, Joo I, Lee ES, Sohn JY, Jang SK, et al. Hepatic fibrosis: prospective comparison of mr elastography and us shear-wave elastography for evaluation. Radiology 2014;273:772-82. doi : 10.1148/radiol.14132000

153. Singh S, Venkatesh SK, Wang Z, Miller FH, Motosugi U, Low RN, et al. Diagnostic performance of magnetic resonance elastography in staging liver fibrosis: a systematic review and meta-analysis of individual participant data. Clin Gastroenterol Hepatol 2015;13:440-51.e446. doi : 10.1016/j. cgh.2014.09.046

154. Loomba R, Cui J, Wolfson T, Haufe W, Hooker J, Szeverenyi N, et al. Novel 3d magnetic resonance elastography for the noninvasive diagnosis of advanced ibrosis in nafld: a prospective study. Am J Gastroenterol 2016;111:986-94. doi:10.1038/ajg.2016.65

155. Singh S, Venkatesh SK, Loomba R, Wang Z, Sirlin C, et al. Magnetic resonance elastography for staging liver fibrosis in non-alcoholic fatty liver disease: a diagnostic accuracy systematic review and individual participant data pooled analysis. Eur Radiol 2015;26:1431-40. doi:10.1007/s00330-015$3949-\mathrm{z}$ 